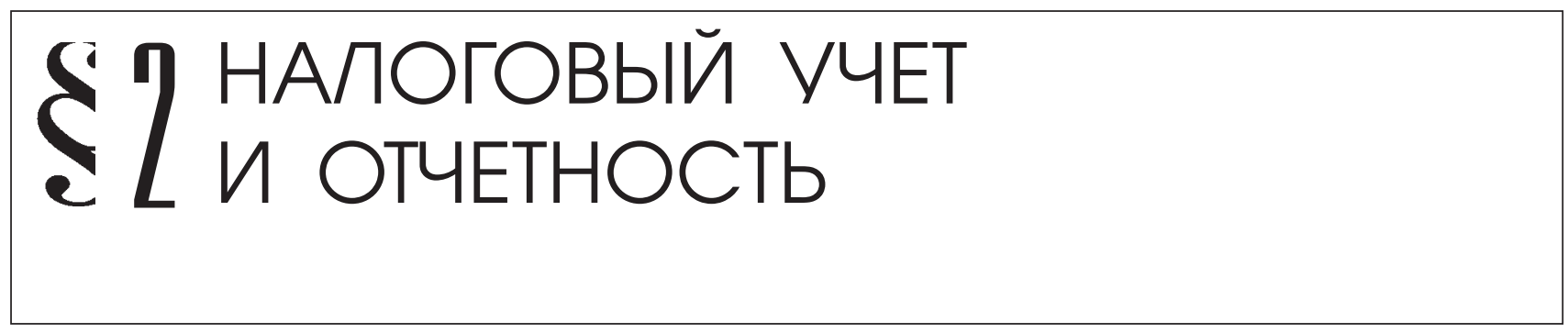

Ермакова М.С.

\title{
УЧЕТНАЯ ПОЛИТИКА ДЛЯ ЦЕЛЕЙ НАЛОГОВОГО УЧЕТА АГРОХОЛДИНГА
}

Аннотация: В статье раскрыта сущуность и обоснована необходимость разработки учетной политики для целей налогового учета агрохолдинга. Дано понятие агрохолдинга. Рассмотрены особенности налоговых отнотений холдинговых компаний с бюджетом. Раскрыт порядок составления налоговой учетной политики в агрохолдине. Систематизированы правила формирования учетной политики для целей бухгалтерского учета и налогообложения.

Ключевые слова: Налоги и налогообложение, агрохолдинг, компания, учетная политика, налоговый учет, бухгалтерский учет, эффективность, правила формирования, налоговые режимы, документ

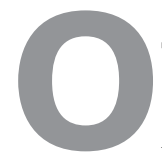

дной из современных форм развития сельскохозяйственного производства является создание и функционирование агрохолдингов, как наиболее жизнеспособных и эффективных форм организации не только финансового капитала, но и производственного потенциала.

Агрохолдинг представляет собой объединение экономически и технологически взаимосвязанных предприятий и организаций разных форм собственности на основе слияния их капитала, обеспечивающего право одного из них определять стратегию и тактику развития коллективного производства. Такие компании ведут высоко диверсифицированную деятельность, имеют территориально распределенную структуру, сложную многоуровневую систему управления. ${ }^{1}$

\footnotetext{
1 Глущенко A.B. Методология внутренней стандартизации учета в агрохолдингах [монография]/ А.В. Глущенко; гос. Образовательное учреждение высш. проф. образования «Волгогр. гос. ун-т» науч. Ред. Л.В. Перекрестова - Волгоград: Изд-во ВолГу, 2008. - 372 с.
}

Для эффективного руководства деятельностью агрохолдинга необходимо располагать полной, точной, объективной, своевременной и сопоставимой информацией. Для организации и постановки учетной системы, в рамках которой происходит формирование подобной информации, необходима эффективная учетная политика. ${ }^{2}$

Грамотно разработанная учетная политика дает возможность повысить привлекательность экономических субъектов, работающих в агропромышленном комплексе, и тем самым, активизировать поток капиталовложений в отрасль. ${ }^{3}$

\footnotetext{
${ }^{2}$ Шакина О.В. Проблемы формирования эффективной учетной политики потребительских обществ/ Вестник Казанского государственного аграрного университета. 2010. Т. 15. № 1. С. 89-92.

${ }^{3}$ Ермакова М.С. Формирование учетной политики сельскохозяйственной организации/ Матариалы научной сессии, г. Волгоград, 23-27 апр. 2012г. [Текст]. - Вып. 3: Мировая экономика и финансы/ Федер. гос. бюдж. образоват. учреждение высш. проф. образования «Волгогр. гос. ун-т»; редкол.: А.Э. Калинина (отв. ред.) [и др.]. Волгоград: Изд-во ВолГУ, 2012. - 468 с.
} 
Согласно гл. 25 Налогового кодекса РФ всем предприятиям независимо от организационно-правовой формы, формы собственности и осуществляемых ими видов деятельности необходимо в обязательном порядке составлять учетную политику для целей налогового учета. ${ }^{4}$

Учетная политика для целей налогообложения - это выбранная совокупность допускаемых Налоговым Кодексом способов (методов) определения доходов и (или) расходов, их признания, оценки и распределения, а также учета иных необходимых для целей налогообложения показателей финансово-хозяйственной деятельности налогоплательщика ${ }^{5}$.

Поэтому, основная задача, которую необходимо решить организации при составлении учетной политики для целей налогообложения, - это выбор способов и методов учета доходов и расходов, применительно к которым законодательством предложена вариантность или по которым отсутствуют законодательные нормы.

Действующее налоговое законодательство не рассматривает группу компаний как единого налогоплательщика. Однако в налоговых отношениях холдинговых компаний с бюджетом существуют свои особенности, которые заключаются в следующем:

- в качестве налогоплательщика выступает каждый участник холдингового объединения самостоятельно. Каждая организация производит уплату налогов и сборов в соответствии с существующим порядком, взаимодействует с налоговыми органами по месту регистрации и несет установленную законом ответственность.

- головная компания выступает и как отдельный плательщик налогов и сборов по деятельности своей компании, и, одновременно, регулирует процесс налогообложения группы путем:

\footnotetext{
${ }^{4}$ Кушнаренко T.B. Актуальные вопросы формирования учетной политики в организациях/ Учет и статистика. 2008. № 11. С. 93-98.

${ }^{5}$ Налоговый кодекс Российской Федерации. Часть первая/Под общей ред. В.И. Слома.- М.: Статут.
}

1) формирования налоговой политики группы в целом и каждого конкретного участника;

2) разработки системы налогового учета;

3) осуществления контроля над правильностью начисления и своевременностью уплаты налогов и сборов каждым участником группы;

4) регулирования уровня цен по сделкам между компаниями-участниками холдинга в случае, когда эти компании признаются взаимозависимыми согласно действующему законодательству.

- головная компания и дочерние (зависимые) общества несут взаимную ответственность за неуплату налогов.

Обязанность по составлению и принятию учетной политики для целей налогообложения появилась одновременно с формированием новой системы налогообложения - в начале 1990-х гг. С выходом первых глав части второй Налогового кодекса Российской Федерации в деловой оборот было введено понятие «учетная политика для целей налогообложения».

В настоящее время обязанность по составлению и принятию учетной налоговой политики закреплена в нескольких главах Налогового кодекса Российской Федерации, но, несмотря на это единого порядка ее составления в действующем налоговом законодательстве не предусмотрено.

До 2007 года учетная политика была единая для и бухгалтерского учета, и для налогообложения. С 01.01.07 г. появилась обязанность для всех организаций иметь учетную политику для налогообложения. При этом, не определено будет ли это отдельный документ, либо отдельный раздел единого документа по учетной политики. ${ }^{6}$ Мы считаем, что учетная политика для целей налогового учета агрохолдинга должна быть оформлена отдельным документом.

\footnotetext{
${ }^{6}$ Рачинский А.В., Шатина Е.Н. Особенности формирования учетной политики по единому сельскохозяйственному налогу для налогообложения /Все для бухгалтера. 2009. № 3. C. 2-5.
} 


\section{Налоги и налогообложение - №4(106) • 2013}

Необходимость разработки отдельного документа, определяющего учетную политику организации для целей налогообложения и входящего в систему ее внутреннего нормативного регулирования, обусловлена, по нашему мнению, следующими причинами:

1. Включение в приказ по учетной политике для целей бухгалтерского учета положений, касающихся налогообложения организации не обосновано. Так как в соответствии с п. 2 ПБУ 1/2008 «Учетная политика организации»: «... под учетной политикой организации понимается принятая ею совокупность способов ведения бухгалтерского учета».

2. Налоговое законодательство, также как и нормативные документы по бухгалтерскому учету, содержит ряд норм, позволяющих организации производить выбор из нескольких альтернативных вариантов.

3. По некоторым вопросам налоговое законодательство устанавливает только общие нормы, но не содержит конкретных способов исчисления налогов.

4. Налоговое законодательство может содержать «противоречия и неясности», на которые имеется прямая ссылка в п. 7 ст. Налогового кодекса Российской Федерации. Таким образом, формирование учетной политики для целей налогообложения предоставляет возможность аргументировано доказать наличие «противоречий и неясностей» в налоговом законодательстве и обосновать выбранный вариант исчисления налогооблагаемой базы, и, следовательно, таким образом минимизировать свои налоговые риски.

Учетная политика для целей налогообложения, как и для целей бухгалтерского учета, должна утверждаться приказом руководителя организации. Утвержденной формы такого документа нет, поэтому он утверждается в произвольной форме. В учетной политике для целей налогообложения агрохолдингов при применении общего режима налогообложения из указанных выше глав Налогового кодекса должны быть прописаны положения в отношении налога на прибыль организаций и налога на добавленную стоимость.

Однако в соответствии с действующим налоговым законодательством компании агрохолдинга могут применять помимо общего режима налогообложения следующие налоговые режимы:

- система налогообложения в виде единого сельскохозяйственного налога (ЕСХН);

- упрощенная система налогообложения ( $\mathrm{YCH})$;

- система налогообложения в виде единого налога на вмененный доход (ЕНВД);

- общая система налогообложения (ОСНО) наряду с системой налогообложения в виде единого налога на вмененный доход (ЕНВД);

- упрощенная система налогообложения (УСН) наряду с системой налогообложения в виде единого налога на вмененный доход (ЕНВД).

При применении компанией агрохолдинга только специального режима в виде ЕНВД нет необходимости в формировании учетной политики для целей налогообложения.

В отношении компаний агрохолдинга, применяющих только упрощенную систему налогообложения и единый сельскохозяйственный налог, существует самостоятельная проблема формирования учетной политики. В случае, когда объектом налогообложения единым налогом при применении упрощенной системы налогообложения является валовая выручка, то в разработке учетной политики и установлении каких-либо ее элементов нет необходимости. Если же объект налогообложения, доходы, уменьшенные на величину произведенных расходов или уплачивается единый сельскохозяйственный налог, то определение затратной части налоговой базы по главам 26.1 «Система налогообложения в виде единого сельскохозяйственного налога» и 26.2 «Упрощенная система налогообложения» Налогового кодекса Российской Федерации на- 
прямую связывается с принципами формирования расходов для целей налогообложения прибыли по главе 25 «Налог на прибыль организаций» Налогового кодекса Российской Федерации.

Расходы в этом случае, считаем более целесообразно, собирать на базе, установленной в этих компаниях системы бухгалтерского учета.

При составлении учетной политики для целей налогового учета агрохолдинга мы рекомендуем соблюдать следующий порядок:

- для всех компаний интегрированной агроструктуры выбрать один способ из нескольких, регулирующих порядок определения налоговой базы и исчисления тех или иных налогов и сборов в Российской Федерации, которые допускает Налоговый кодекс Российской Федерации;

- выбранные способы учета установить для всех компаний агрохолдинга;

- выбранные способы учета установить на длительный срок - на отчетный год;

- выбранные варианты налогового учета закрепить соответствующим организационнораспорядительным документом.

Согласност. 313 Налогового кодекса Российской Федерации изменение порядка учета отдельных хозяйственных операций и (или) объектов в целях налогообложения может осуществляться в случаях:

- изменения законодательства;

- изменения применяемых методов учета.?

При этом решения о любых изменениях должны отражаться в учетной политике для целей налогообложения и применяться с начала нового налогового периода. Также в ст. 313 Налогового кодекса установлена возможность внесения дополнений в учетную политику для целей налогообложения в случае, когда налогоплательщик начал осуществлять новые виды деятельности. Он обязан определить и отразить в данной учетной политике принципы и порядок отражения этих видов деятельности для целей налогообложения.

Изучив общие положения нормативно-законодательной базы, определяющие учетную политику, считаем, что более целесообразно строить учетную политику для целей налогообложения так, чтобы она как можно меньше расходилась с учетной политикой для целей бухгалтерского учета.

Несовпадение тех или иных вариантов в бухгалтерском и налоговом учете приводит к необходимости применения Положения по бухгалтерскому учету «Учет расчетов по налогу на прибыль» ПБУ 18/02, утвержденного приказом Минфина России от 19 ноября 2002 г. № 114н.

В этой связи считаем необходимым конкретизировать требования к формированию учетной политики в системе бухгалтерского учета и для целей налогообложения (табл. 1).

Таблиия 1

Правила формирования учетной политики для цеелей бухгалтерского учета и налогообложения

\begin{tabular}{|c|c|c|}
\hline $\begin{array}{c}\text { Правила } \\
\text { формирования } \\
\text { учетной политики }\end{array}$ & $\begin{array}{c}\text { Учетная политика для целей бухгал- } \\
\text { терского учета }\end{array}$ & $\begin{array}{c}\text { Учетная политика для целей } \\
\text { налогообложения }\end{array}$ \\
\hline 1 & 2 & 3 \\
\hline $\begin{array}{c}\text { Порядок разработки } \\
\text { и утверждения } \\
\text { Формируется главным бухгалтером } \\
\text { или иным лицом, на которое в соответ- } \\
\text { стви с законодательством Российской }\end{array}$ & Не установлено \\
\hline
\end{tabular}

${ }^{7}$ Налоговый кодекс Российской Федерации. Часть первая/Под общей ред. В.И. Слома.- М.: Статут. 


\section{Налоги и налогообложение - №4(106) • 2013}

\begin{tabular}{|c|c|c|}
\hline & $\begin{array}{c}\text { Федерации возложено ведение бух- } \\
\text { галтерского учета и утверждается } \\
\text { руководителем организации (п. } 4 \\
\text { ПБУ 1/2008 «Учетная политика орга- } \\
\text { низации) }\end{array}$ & \\
\hline Оформление & $\begin{array}{c}\text { Приказ, распоряжение и т.п. органи- } \\
\text { зации (п. } 8 \text { ПБУ 1/2008 «Учетная по- } \\
\text { литика организации) }\end{array}$ & $\begin{array}{c}\text { Приказ, распоряжение по ор- } \\
\text { ганизации (ст. } 167 \text { Налогового } \\
\text { кодекса Российской Федера- } \\
\text { ции) }\end{array}$ \\
\hline $\begin{array}{c}\text { Сроки применения } \\
\text { избранных способов } \\
\text { ведения учета }\end{array}$ & $\begin{array}{c}\text { С } 1 \text { января года, следующего за годом } \\
\text { утверждения приказа, распоряжения } \\
\text { (п. } 9 \text { ПБУ 1/2008 «Учетная политика } \\
\text { организации) }\end{array}$ & $\begin{array}{c}\text { С } 1 \text { января года, следующего } \\
\text { за годом утверждения (ст. } 167 \\
\begin{array}{c}\text { Налогового кодекса Россий- } \\
\text { ской Федерации) }\end{array}\end{array}$ \\
\hline $\begin{array}{c}\text { Срок утверждения и } \\
\text { применения вновь соз- } \\
\text { данной организацией } \\
\text { или } \\
\text { организацией, } \\
\text { возникшей в результа- } \\
\text { те реорганизации } \\
\end{array}$ & $\begin{array}{c}\text { Не позднее } 90 \text { дней со дня государ- } \\
\text { ственной регистрации юридического } \\
\text { лица. Применяется со дня государ- } \\
\text { ственной регистрации юридического } \\
\text { лица (п. } 9 \text { ПБУ 1/2008 «Учетная по- } \\
\text { литика организации) }\end{array}$ & $\begin{array}{c}\text { Не позднее окончания первого } \\
\text { налогового периода (квартала) } \\
\text { (ст. } 167 \text { Налогового кодекса } \\
\text { Российской Федерации) }\end{array}$ \\
\hline $\begin{array}{c}\text { Обязательность } \\
\text { применения }\end{array}$ & $\begin{array}{c}\text { Обязательно применяются всеми } \\
\text { филиалами, представительствами и } \\
\text { иными подразделениями организации } \\
\text { (включая выделенные на отдельный } \\
\text { баланс), независимо от их места на- } \\
\text { хождения (п. } 9 \text { ПБУ 1/2008 «Учетная } \\
\text { политика организации) }\end{array}$ & $\begin{array}{c}\text { Обязательно применяется } \\
\text { всеми обособленными под- } \\
\text { разделениями (ст. } 167 \text { На- } \\
\text { логового кодекса Российской } \\
\text { Федерации) }\end{array}$ \\
\hline
\end{tabular}

Продолжение таблицы 1

\begin{tabular}{|c|c|c|}
\hline 1 & 2 & 3 \\
\hline $\begin{array}{c}\text { Условия, при которых } \\
\text { могут вноситься } \\
\text { изменения в учетную } \\
\text { политику }\end{array}$ & $\begin{array}{c}\text { 1. В случае изменения законодатель- } \\
\text { ства и (или) нормативных актов по } \\
\text { бухгалтерскому учету; } \\
\text { 2. В случае разработки организацией } \\
\text { новых способов ведения бухгалтер- } \\
\text { ского учета; } \\
\text { 3. При существенном изменении усло- } \\
\text { вий хозяйствования (п. } 10 \text { ПБУ 1/2008 } \\
\text { «Учетная политика организации) }\end{array}$ & $\begin{array}{c}\text { 1. В случае изменения зако- } \\
\text { нодательства } \\
\text { 2. В случае изменения при- } \\
\text { меняемых способов ведения } \\
\text { учета } \\
\text { 3. При осуществлении но- } \\
\text { вых видов деятельности } \\
\text { (ст. } 313 \text { Налогового кодекса } \\
\text { Российской Федерации) }\end{array}$ \\
\hline
\end{tabular}


Налоговый учёт и отчетность

\begin{tabular}{|c|c|c|}
\hline $\begin{array}{c}\text { Сроки вступления в } \\
\text { действие изменений, } \\
\text { внесенных в учетную } \\
\text { политику }\end{array}$ & $\begin{array}{l}\text { Изменение учетной политики произ- } \\
\text { водится с начала отчетного года, если } \\
\text { иное не обуславливается причиной } \\
\text { такого изменения (п. } 12 \text { ПБУ } 1 / 2008 \\
\text { «Учетная политика организации) }\end{array}$ & $\begin{array}{c}\text { 1. При изменении приме- } \\
\text { няемых методов учета при- } \\
\text { нимается с начала нового } \\
\text { налогового периода; } \\
\text { 2. При изменении законода- } \\
\text { тельства о налогах и сборах } \\
\text { не ранее чем с момента } \\
\text { вступления в силу измене- } \\
\text { ний норм указанного зако- } \\
\text { нодательства (ст. } 313 \text { Нало- } \\
\text { гового кодекса Российской } \\
\text { Федерации) }\end{array}$ \\
\hline $\begin{array}{l}\text { Условия, при которых } \\
\text { корректировки } \\
\text { учетной политики не } \\
\text { являются } \\
\text { изменениями }\end{array}$ & $\begin{array}{c}\text { Утверждение способа ведения бух- } \\
\text { галтерского учета фактов хозяйствен- } \\
\text { ной деятельности, которые отличны } \\
\text { по существу от фактов, имевших } \\
\text { место ранее, или возникли впервые } \\
\text { в деятельности организации (п. } 10 \\
\text { ПБУ 1/2008 «Учетная политика орга- } \\
\text { низации) }\end{array}$ & Не определены \\
\hline $\begin{array}{l}\text { Последствия отсут- } \\
\text { ствия установления в } \\
\text { учетной политике вы- } \\
\text { бранного способа }\end{array}$ & Не определены & $\begin{array}{c}\text { Налоговым кодексом ут- } \\
\text { верждается способ, который } \\
\text { будет применяться для опре- } \\
\text { деления налоговой базы в } \\
\text { процессе контроля }\end{array}$ \\
\hline
\end{tabular}

Источник: составлено автором

Исходя из анализа налоговых режимов, которые могут применять компании агрохолдинга, отметим, что существует реальная возможность тесной интеграции учетной политики для целей бухгалтерского учета и налогообложения.

Таким образом, разработка учетной политики как для налогового учета входит в число важнейших задач, решаемых главным бухгалтером агрохолдинга. От того насколько грамотно составлена налоговая учетная политика во многом зависит эффективность учетной работы на предприятии, поскольку она является важным и неотъемлемым элементом системы внутреннего контроля агрохолдинга.

\section{Библиография:}

1. Глущенко А.В. Методология внутренней стандартизации учета в агрохолдингах [монография]/А.В. Глущенко; гос. Образовательное учреждение высш. проф. образования «Волгогр. гос. ун-т» науч. Ред. Л.В. Перекрестова - Волгоград: Изд-во ВолГу, 2008. - 372 с.

2. Глущенко А.В., Ермакова М.С. Основные принципы формирования единой учетной политики в агрохолдингах // Фундаментальные исследования, № 11 (часть 3). 2012. - стр. 755-758; 


\section{Налоги и налогообложение - №4(106) • 2013}

3. Ермакова М.С. Формирование учетной политики сельскохозяйственной организации/ Матариалы научной сессии, г. Волгоград, 2327 апр. 2012г. [Текст]. - Вып. 3: Мировая экономика и финансы/ Федер. гос. бюдж. образоват. учреждение высш. проф. образования «Волгогр. гос. ун-т»; редкол.: А.Э. Калинина (отв. ред.) [и др.]. - Волгоград: Изд-во ВолГУ, 2012. - 468 с.

4. Королева Н.А. Учетная политика организаций в целях финансового, управленческого и налогового учета// Вестник Белгородского университета кооперации, экономики и права. 2010. № 4. С. 259-262.

5. Крапивина Л.Н., Лунева Т.А. Учетная политика сельскохозяйственных организаций для целей налогового учета// Экономика сельскохозяйственных и перерабатывающих предприятий. 2006. № 12. С. 44-45.

6. Кушнаренко Т.В. Актуальные вопросы формирования учетной политики в организациях/ Учет и статистика. - 2008. № 11. С. 93-98.

7. Налоговый кодекс Российской Федерации. Часть первая/Под общей ред. В.И. Слома.М.: Статут.

8. Рачинский А.В., Шатина Е.Н. Особенности формирования учетной политики по единому сельскохозяйственному налогу для налогообложения/Все для бухгалтера. 2009. №3. С. 2-5.

9. Трушицына А.Ю. Учетная политика для целей налогового учета// Бухгалтерский учет в бюджетных и некоммерческих организациях. 2012. № 12. С. 21-27.

10. Шакина О.В. Проблемы формирования эффективной учетной политики потребительских обществ/ Вестник Казанского государственного аграрного университета. 2010. T. 15. № 1. C. 89-92.

\section{References (transliteration):}

1. Glushhenko A.V. Metodologija vnutrennej standartizacii ucheta $\mathrm{v}$ agroholdin- gah [monografija]/A.V. Glushhenko; gos. Obrazovatel'noe uchrezhdenie vyssh. prof. obrazovanija «Volgogr. gos. un-t» nauch. Red. L.V. Perekrestova - Volgograd: Izd-vo VolGu, 2008. - 372 s.

2. Glushhenko A.V., Ermakova M.S. Osnovnye principy formirovanija edinoj uchetnoj politiki v agroholdingah // Fundamental'nye issledovanija, № 11 (chast’ 3). 2012. - str. 755-758;

3. Ermakova M.S. Formirovanie uchetnoj politiki sel'skohozjajstvennoj organizacii/ Matarialy nauchnoj sessii, g. Volgograd, 23-27 apr. 2012g. [Tekst]. - Vyp. 3: Mirovaja jekonomika i finansy/ Feder. gos. bjudzh. obrazovat. uchrezhdenie vyssh. prof. obrazovanija «Volgogr. gos. un-t»; redkol.: A.Je. Kalinina (otv. red.) [i dr.]. - Volgograd: Izd-vo VolGU, 2012. - 468 s.

4. Koroleva N.A. Uchetnaja politika organizacij v celjah finansovogo, upravlencheskogo i nalogovogo ucheta// Vestnik Belgorodskogo universiteta kooperacii, jekonomiki i prava. 2010. № 4. S. 259-262.

5. Krapivina L.N., Luneva T.A. Uchetnaja politika sel'skohozjajstvennyh organizacij dlja celej nalogovogo ucheta// Jekonomika sel'skohozjajstvennyh i pererabatyvajushhih predprijatij. 2006. № 12. S. 44-45.

6. Kushnarenko T.V. Aktual'nye voprosy formirovanija uchetnoj politiki v organizacijah/ Uchet i statistika. - 2008. № 11. S. 93-98.

7. Nalogovyj kodeks Rossijskoj Federacii. Chast' pervaja/Pod obshhej red. V.I. Sloma.-M.: Statut.

8. Rachinskij A.V., Shatina E.N. Osobennosti formirovanija uchetnoj politiki po edinomu sel'skohozjajstvennomu nalogu dlja nalogooblozhenija/Vse dlja buhgaltera. 2009. № 3. S. 2-5.

9. Trushicyna A.Ju. Uchetnaja politika dlja celej nalogovogo ucheta// Buhgalterskij uchet v bjudzhetnyh i nekommercheskih organizacijah. 2012. № 12. S. 21-27.

10. Shakina O.V. Problemy formirovanija jeffektivnoj uchetnoj politiki potrebitel'skih obshhestv/ Vestnik Kazanskogo gosudarstvennogo agrarnogo universiteta. 2010. T. 15. № 1. S. 89-92. 